\title{
The Jesuit Contribution to the Geographical Knowledge of India in the Eighteenth Century
}

\author{
Manonmani Restif-Filliozat \\ Managing Archivist, FranceArchives Portal \\ mfilliozat@wanadoo.fr
}

\begin{abstract}
While the mapping activities of French Jesuits in China and New France have been extensively studied, those in India have received less attention. While benefiting from the French crown's interest in using the Jesuits as a tool for empire, they did not help develop an overarching imperial structure like that of Spain and Portugal or that of the Manchu Qing Dynasty. The work of Jean-Venant Bouchet (1655-1732), Louis-Noël de Bourzes (1673-1735), Claude Moriset (1667-1742), Claude-Stanislas Boudier (16861757), Gaston-Laurent Cœurdoux (1691-1779), and many others was instead important in building linkages between institutions and individuals in Europe and India. It further allowed commercial cartographers in Paris and London like Guillaume Delisle (1675-1726), Jean-Baptiste d'Anville (1697-1782), and James Rennell (1742-1830) to develop a more sophisticated picture of the interior of India.
\end{abstract}

\section{Keywords}

Jesuit Cartography - India - Guillaume Delisle - Étienne Souciet - Pondicherry France - Jean-Baptiste d'Anville - Louis-Noël de Bourzes - Claude Moriset - ClaudeStanislas Boudier - Jean-Venant Bouchet - Gaston-Laurent Cœurdoux - Académie des Sciences

(C) MANONMANI RESTIF-FILLIOZAT, 2019 | DOI:10.1163/22141332-00601006

This is an open access article distributed under the terms of the prevailing CC-BY-NC license at the time of publication. 
On n'a eu jusqu'ici que des idées assez confuses de cette partie de l'Inde méridionale située entre la côte de Coromandel et la côte de Malabar: comme il n'y a que nos missionnaires qui aient pénétré dans ces terres, où ils travaillent depuis plus de cent ans à la conversion des Indiens idolâtres, il n'y a qu'eux qui puissent nous en donner des connaissances sûres.

JEAN-VENANT BOUCHET (1655-1732), APRIL 19, $1719^{1}$

Even though the Jesuit Antonio Monseratte (1536-16oo) drew a map of North India in 1580 after a trip up to Kabul with Akbar's army, the Jesuit order only began to contribute significantly to the progress of geographical knowledge of India after 170o. Even so, they remained at the forefront of cartographic knowledge of the interior. They published maps and geographical information in the Lettres édifiantes et curieuses, at a time when no European had started geodesic surveys and few, as Bouchet notes, understood the geography of India beyond the coasts. ${ }^{2}$ Scientific reforms in France helped drive this shift. Paris became a leading capital for the sciences thanks to the foundation of the Académie des Sciences in 1666 and the Observatory in 1667, tasked by Louis XIV (r.1643-1715) with the ambitious project of collecting data to improve the safety of navigation, life and commerce in its new colonies. The academicians developed a world network of correspondents including the very active Jesuit

1 Jean-Venant Bouchet to P.***, Pondicherry, April 19, 1719, in Lettres édifiantes et curieuses concernant l'Asie, l'Afrique et l'Amérique avec quelques relations nouvelles des missions et des notes géographiques et historiques, ed. Louis Aimé-Martin (Paris: Mairet et Fournier, 1849), 548.

2 British surveys in Bengal started in the 1760 s whereas the French ingénieurs militaires and ingénieurs géographes, active mainly from the 1750 os onwards, made plans of seats of wars or fortresses. See Matthew H. Edney, Mapping an Empire: The Geographical Construction of British India 1765-1843 (Chicago: University of Chicago Press, 1997), 3-8. For knowledge formation during this period see in particular Kapil Raj, "Colonial Encounters and the Forging of New Knowledge and National Identities: Great Britain and India, 1760-1850," Osiris 15, no. 2 (2000): 119-34; Kapil Raj, Relocating Modern Science: Circulation and the Construction of Knowledge in South Asia and Europe (New York: Palgrave, 2007); and more generally Simon Schaffer, Linda Roberts, Kapil Raj and James Delbourgo, The Brokered World: Go-Betweens and Global Intelligence, 1770-1820 (Sagamore Beach: Science History Publications, 2009). 
missionaries. ${ }^{3}$ But the shift also involved the development of commercial printed cartography in Paris as well as London, and cartographers such as Guillaume Delisle (1675-1726), Jean-Baptiste d'Anville (1697-1782), and James Rennell (1742-1830) acknowledged using data collected by Jesuit missionaries. Finally, as historians of science such as Kapil Raj have suggested, much of this work involved go-betweens in India, challenging ideas of the linear development of European science and its propagation in India during this period and highlighting the two-way transmission of knowledge. ${ }^{4}$ In this way, the Jesuit mapping of India reveals the same complexity and the same ambiguity as historians of cartography have described for maps of Central and South America and the Qing Empire, yet without the same kinds of overarching imperial structures developed by the Portuguese, Spanish and the Manchus. ${ }^{5}$

In the classic studies of Reginald Philimore and Susan Gole or the recent work of Rajesh Kocchar, Jesuit maps are mentioned as landmarks of progress in the geographical knowledge of India. ${ }^{6}$ The French Jesuits were indeed a special case. The first French Jesuits arrived in India in 1689 after their expulsion from Siam, where they had been sent as mathématiciens du roi. They founded the mission of Carnate attached to the assistance of France (Gallia), leaving the province of Malabar from Cape Comorin to Andhra Pradesh and the province of Goa from Mysore to North India to the assistance of Portugal

3 James E. McClellan III and François Regourd, The Colonial Machine: French Science and Overseas Expansion in the Old Regime (Turnhout: Brepols, 2011), 72-84. Monique Pelletier, Cartographie de la France et du monde de la Renaissance au siècle des lumières (Paris: Bibliothèque nationale de France, 2001), 81-82.

4 See Joan-Pau Rubiés, Travel and Ethnology in the Renaissance: South India Through European Eyes (Cambridge: Cambridge University Press, 2002); Dhruv Raina, "Betwixt Jesuit and Enlightenment Historiography: Jean-Sylvain Bailly's History of Indian Astronomy," Revue d'histoire des mathématiques 9 (2003): 253-306; Kapil Raj, Relocating Modern Science: Circulation and the Construction of Knowledge in South Asia and Europe (New York: Palgrave, 2007); Schaffer et al., Brokered World; Angela Barreto Xavier and Ines G. Županov, Catholic Orientalism: Portuguese Empire, Indian Knowledge (1 $16^{\text {th }}-18$ th Centuries) (Oxford: Oxford University Press, 2014).

5 David Buisseret, "Jesuit Cartography in Central and South America," in Jesuit Encounters in the New World, ed. Joseph A. Gagliano and Charles E. Ronan (Rome: Institutum Historicum SI, 1997), 113-62, here 161; Mario Cams, Companions in Geography. East-West Collaboration in the Mapping of Qing China (c.1685-1735) (Leiden: Brill, 2017), 245-46.

6 Reginald Henry Phillimore, Historical records of the Survey of India. Volume I: 18th Century (Dehradun: Survey of India, 1945), 1; Susan Gole, India within the Ganges (New Delhi: Jayaprints, 1983), 68-69; Rajesh K. Kocchar, "Secondary Tools of Empire: Jesuit Men of Science in India," in Discoveries, Missionary Expansion and Asian Cultures, ed. Teotonio R. de Souza (New Delhi: Concept Publishing Company, 1994), 175-83. 
(Lusitania). ${ }^{7}$ Louis XIV authorized these French missionaries in March 1695 to make all observations for the perfection of arts, sciences and navigation. ${ }^{8}$ Under the protection and for the glory of their king, French Jesuits could thus escape the limits of the Portuguese Padroado, sending reports to the Superior General or other Jesuits in France. They collected manuscripts for the Bibliothèque du Roi and sent information to the Parisian scientific institutions, thus replacing Lisbon and even Rome as centers of Catholic knowledge collection about India. ${ }^{9}$

Jesuits needed to know the territory where they had settled a mission, and maps could be tools of decision-making as well as tools of propaganda. ${ }^{10}$ From the founding of the order, Ignatius of Loyola $(c .1491-1556)$ asked to the missionaries to send reports on their settlements. He stressed the importance of human geography, wanting not only details on the geographical location, the region, and climate, but also concerning the inhabitants, their customs, and their political and economical situation. Maps accompanying reports became, by the late sixteenth century, useful media to describe a region. During the seventeenth century, geography became an important subject in Jesuit colleges, especially in France. Taught along with mathematics and rhetoric, it combined elements from the Ancients with the new geography based on explorations. Maps of the world were hanged on the walls of the colleges, creating emulation for missions. This contributed to the emergence of a strong school of geography in France towards the end of the seventeenth century, when the missions took on a national dimension. ${ }^{11}$

From the end of the sixteenth century onwards the Jesuits published translations of annual letters or memoirs of Jesuits in Asia, a tradition perpetuated in the thirty-four volumes of the Lettres édifiantes et curieuses published from 1703 onwards in Paris by Charles Le Gobien (1703-8), Jean-Baptiste Du Halde (1708-43), and Louis Patouillet (1746-76). The editors tried to keep a balance between pious texts about conversions and martyrdoms with ethnographical and geographical information, which could be of interest for a broader

7 Louis Carrez, Atlas geographicus Societatis Jesu (Paris: Georges Colombier, 1900), 54-55.

8 Archives nationales, Paris [hereafter AN]. Mar B ${ }^{2} 105$ f. 54-55. Patent letters for the Jesuits in the East Indies, March 1695 .

9 Xavier and Županov, Catholic orientalism, 305-6. See xxix-xxx on the gradual shift of the central informational hub from Lisbon to Rome and Paris.

10 Lucia Nuti, "La cartographie jésuite: Du plan de quartier à l'atlas du monde," in François de Dainville S.J. (1909-1971) pionnier de l'histoire de la cartographie et de l'éducation, ed. Catherine Bousquet-Bressolier (Paris: École des chartes, 2004), 187-201.

11 François de Dainville, La géographie des humanistes (Paris: Beauchesne, 1940), 113-14, 167, 205-321. 
public. ${ }^{12}$ Thomas Gouye (1650-1728), an active member of the Académie des Sciences, and Étienne Souciet (1671-1744), a contributor to the Mémoires de Trévoux and librarian in the Collège Louis-le-Grand, were also diligent correspondents in Paris of the missionaries in Asia. They published information on India along with observations made in China. ${ }^{13}$ These and other publications included maps of India, notably a map of extreme south of India in the 1692 Observations physiques et mathématiques, maps of South India in volume fifteen of the Lettres édifiantes et curieuses (1722) and another in volume twenty three (1738), adopting a marketing practice common among Dutch, French and British booksellers. ${ }^{14}$

The 1722 map of South India was based on a map sent in 1719 by Jean-Venant Bouchet (1655-1732), one of the most prominent Jesuits in India at the beginning of the eighteenth century. He followed accommodationist practices under the influence of João de Brito (1647-93), and is credited of many thousands of conversions, defending the practices of the mission against Clement

12 Isabelle Landry-Déron, "Lettres édifiantes et curieuses," in Dictionnaire des orientalistes de langue française, ed. François Pouillon (Paris: IISMM, Karthala, 2012), 593. Previously the Jesuit mission in New France had published at Paris the Relations des Jésuites de la Nouvelle-France (Paris: Sébastien Cramoisy, 1632-73).

13 Thomas Gouye, Observations physiques et mathématiques pour servir à l'histoire naturelle et à la perfection de l'astronomie et de la géographie, envoyées des Indes et de la Chine à l'Académie royale des sciences à Paris, par les pères jésuites, avec les réflexions de Mrs de l'Académie et les notes du P. Gouye, de la Compagnie de Jésus (Paris: Imprimerie royale Jean Anisson, 1692) republished in Mémoires de l'Académie royale des sciences 7 (Paris: Compagnie des Librairies, 1729); Étienne Souciet, Observations mathématiques, astronomiques, géographiques, chronologiques et physiques, tirées des anciens livres chinois, ou faites nouvellement aux Indes et à la Chine, par les Pères de la Compagnie de Jésus (Paris: Rollin, 1729-32).

14 "Carte d'une partie de l'Inde en deça du Gánge" (1692), Observations physiques, facing 16 , see Bibliothèque nationale de France [hereafter Bnf], département Cartes et plans, GE DD-2987 (6908), http://gallica.bnf.fr/ark:/12148/btvib859319og?rk=21459;2, accessed December 7, 2017; "Carte des missions des P.P. de la Compagnie de Jesus dans le Maduré et les royaumes circonvoisins" (1722), Lettres édifiantes et curieuses: Écrites des missions étrangères 13 (Paris: Nicolas Le Clerc and G. Le Mercier, 1731), facing 90, Bnf, département Cartes et plans, CPL GE DD-2987 (6973). http://gallica.bnf.fr/ark:/12148/btvib59628599, accessed December 7, 2017; and Jean-Baptiste d'Anville, "Nouvelle Carte d'une grande partie de la Presqu'Isle des Indes en deça du Gange" (1737), Lettres édifiantes et curieuses 23 (Paris: Nicolas Le Clerc and G. Le Mercier, 1738), facing 104. D'Anville's original printed sheet version (1737) was engraved by Guillaume Delahaye (1725-1802), and there was also a Lettres édifiantes version (1738). See Nicolas Verdier, La carte avant les cartographes. L'avènement du régime cartographique en France au XVIII ${ }^{e}$ siècle (Paris: Publications de la Sorbonne, 2015), 106-8. 
XI's (r.1700-21) envoy Charles-Thomas Maillard de Tournon (1668-1710) in the Indian or Malabar Rites Controversy. He became one of the most important Jesuits advocating for greater geographic knowledge of India. ${ }^{15}$ Bouchet was then superior of the mission of Carnate (1715-25), and he sent the map along with a long letter describing the peninsula. ${ }^{16}$ It gives a comprehensive description of the Indian peninsula including the northern regions, indicating the latitude of many towns along with historical details, largely related to the spread of Christianity. The map itself has scales of latitude $\left(7^{-15^{\circ}}\right)$, longitude $\left(93^{-101^{\circ}}\right.$ east of Hierro), and distances. The cartouche of title bears the ensign of the Jesuits. Though mountains and forests remain figurative and colored with shading, churches and fortresses tend towards the symbolic, although they still have shadows. The eastern Ghats are depicted for the first time on a map published in Europe, and the error in longitude of all places is about two degrees instead of eighteen to twenty degrees on earlier maps. Overall the map indicates a mathematization of cartographic practice, breaking with the use of "narrative figures" described by Michel de Certeau, which, despite the remaining symbols, make the map more "autonomous" and abstract. ${ }^{17}$

Though the German printed edition attributes the map to Bouchet, author of the letter, the actual data seems to have been provided by Louis-Noël de Bourzes (1673-1735) and Claude Moriset (1667-1742). ${ }^{18}$ De Bourzes came from

15 Francis Xavier Clooney, Father Bouchet's India: An Eighteenth-Century Jesuit's Encounter with Hinduism (Chennai: Satya Nilayam Publications, 2005).

16 The Bouchet manuscript map is "Carte des missions des pères de Compagnie de Jésus dans les Indes orientales où l'on a mis les principales églises de la mission de Maduré sous le nom de laquelle sont comptés les missions des mesmes pères dans les royaumes de Tanjaor, Trigerapalli ou Maduré, de Mayssur, de Gingi, de Carnatte, du prince de Marava, des costes de Coromandel, de la Pècherie, de Travancore, de Malabar" (before 1719), Bnf, Pet. Fol. Od 55, view 87. See http://gallica.bnf.fr/ark:/12148/btvib55007288r/f87.item, accessed December 7, 2017, confusingly filed in "Usages du Royaume de Siam: Cartes, plans et vues en 1688." See Roselyne Hurel, Miniatures et peintures indiennes 2 (Paris: Bibliothèque nationale de France, 2011), 159n315.

17 Michel de Certeau, L'invention du quotidien (Paris: Gallimard, 1980), 177-78.

18 The German edition is Joseph Stöcklein, Allerhand so Lehr-als Geist-reiche Brief... (Augsburg: Philipp Martin, 1726). The relevant letter is de Bourzes to Souciet, 1725, Archives des jésuites de la province de France, Paris [hereafter ASJP], G Bro 86 f. 48v. De Bourzes writes, "I have seen this map in the volume of Lettres and was surprised to find the one which I had drawn with the help of the dear friar Moriset, along with the one of Maïssur made by father Jacinthe Serra, Italian of our Company." Souciet published this letter with a few alterations in his Observations mathématiques, 1:180-81. See Carlos Sommervogel ed., Bibliothèque de la Compagnie de Jésus 1 (Louvain: Schepens and Paris: Picard, 189o): 1864-66 and Léon Besse, "Liste alphabétique des missionnaires du Carnatic de la Compagnie de Jésus au XVIII ${ }^{\mathrm{e}}$ siècle," Revue historique de l'Inde française 2 (1918): 12-19. 
the province of Lyon, arrived in India in 1704 and worked in the mission of Madurai. Moriset, born in Paris, entered the novitiate in 169o. He accompanied Guy Tachard in all his trips, teaching hydrography and pilotage in Pondicherry. Not satisfied with the map of 1722 , Souciet asked de Bourzes and Moriset for new maps of South India for his next publication. ${ }^{19}$

Souciet did not end up including maps of India in his publication, but the maps of the missions of Carnate and Mysore that he received after his request seem to have been passed on to d'Anville. This included a manuscript sketch of the area covered by the mission, from Pondicherry to the Krishna River. The places seem to have been mapped in relation to one another, resulting in some distortion, with latitude used to give a sense of the general positions. Important towns, such as the capital of a nabab or other prince, are clearly marked but without any hierarchy as are the Jesuit churches. ${ }^{20}$ As De Bourzes noted in his 1725 letter, Hyacintho Serra (1662-1712) also made a map of the Mysore mission with captions in Portuguese and some translations. It has a scale of latitude and scales of French and Portuguese leagues as well as of a local measure called gaudas. Though rough, it seems to be an edited version of the map. Churches are carefully located by a cross and it gives a good idea of the geographical extent of the Jesuit missions. ${ }^{21}$ After Du Halde collaborated with d'Anville on the Description de la Chine (1735), Du Halde may have also asked him to prepare a map of South India. D'Anville's manuscript map is dated 1737, and it was printed the next year in the Lettres édifiantes. It depicts South India from Cape Comorin to the Krishna River, with scales of latitude and of leagues. The churches are carefully marked as well as political and religious landmarks ${ }^{22}$ (Figure 5.1).

In this way, making geographical notes and taking simple astronomical observations (measuring the altitude of the sun at noon for example) became part of the everyday life of a few eighteenth-century missionaries alongside

19 ASJP, G Bro 88 f.107. Moriset to Souciet, October 14, 1725. Moriset informed Souciet that he was still waiting for materials from the fathers of Carnate.

20 "Essay de carte par estime pour la mission françoise des Jésuites du Carnate" (n.d.) AsJP, G Bro 88 f.158. See also the copy from d'Anville's collection, ["Croquis d'une partie de la côte de Coromandel depuis Pondicherry jusqu'à la rivière de Chrichna avec l'intérieur du pays"], BnF, GE DD-2987 (7003). http://gallica.bnfffr/ark:/12148/btvib59628866/fi.item, accessed June 6, 2018.

21 ASJP, G Bro 88 f.159.

22 The manuscript version is Jean-Baptiste d'Anville, "Presqu'isle des Indes en deçà de Gange: dressée sur les cartes mss des RR. PP. jésuites” (1737), BnF, GED-10597. http://gallica.bnf.fr/ark:/12148/btvib53009180o, accessed June 6, 2018. 


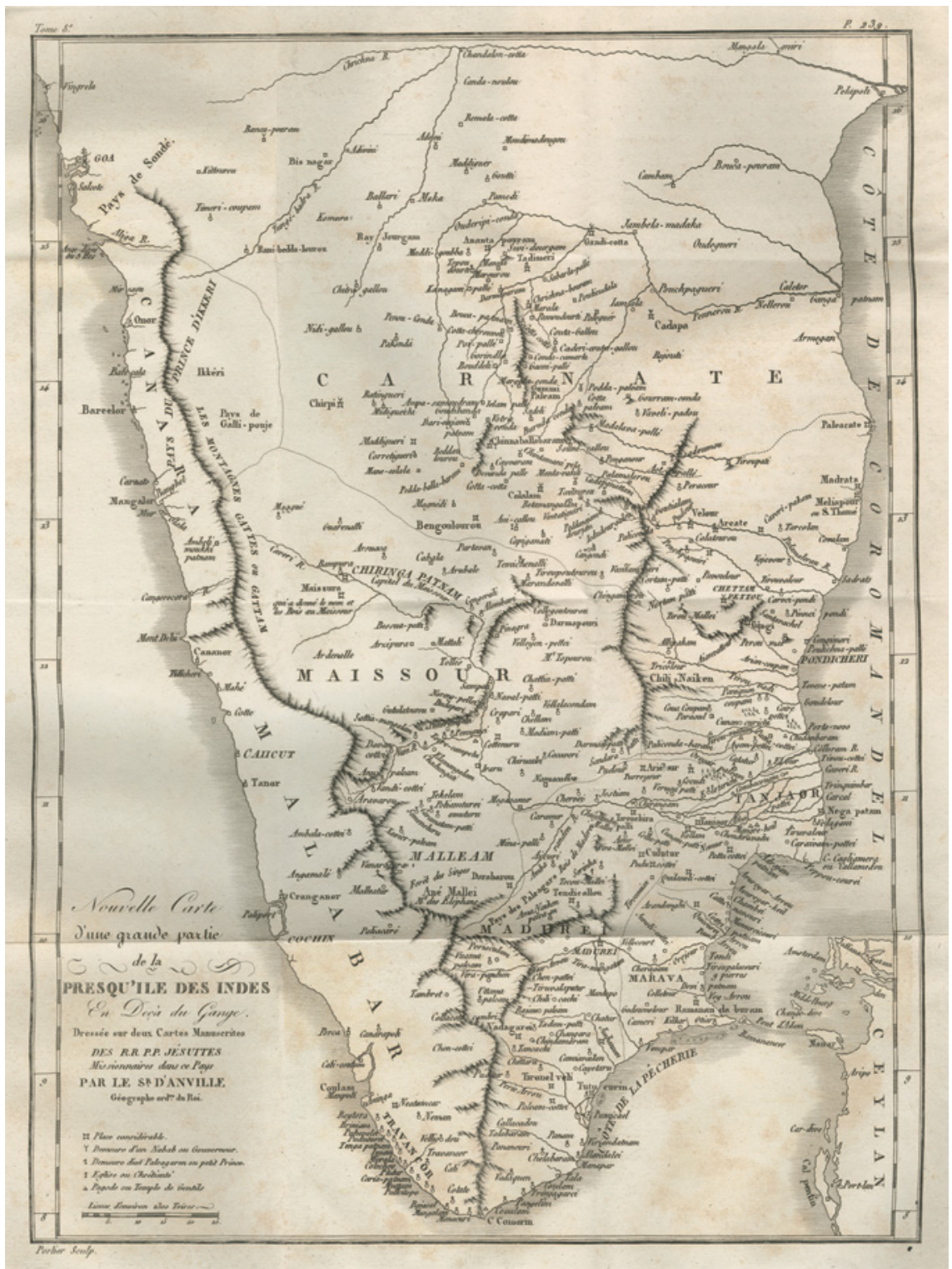

FIG URE 5.1 Jean-Baptiste d'Anville, Nouvelle carte d'une grande partie de la presqu'île des Indes en-deçà du Gange, dressée d'après deux cartes manuscrites des RR PP jésuites, missionnaires dans ce pays (Paris: Porlier, 1781). The original 1737 edition with the Jesuit monogram can be found at http://gallica.bnf.fr/ark:/12148/btvib59730616, accessed March 14, 2018.

PRIVATE COLLECTION (C RESTIF-FILLIOZAT) 
their evangelization work. ${ }^{23}$ If only a few of them like Bouchet, de Bourzes, Moriset or Claude-Stanislas Boudier (1686-1757) were able to draw maps, many others contributed to the mapping project by making observations and carefully noting their itineraries despite their poor conditions of living and the lack of good instruments. ${ }^{24}$ Evidence of this is scattered throughout the archives. In 1725, Gilbert Ducros (1692-1730) complained that he had lost his compass. ${ }^{25}$ René-Memmie Gargam (1686-1754) measured latitudes in various places with a "small instrument" during his trips from Pondicherry to the northern locations of the mission of Carnate. He used the astronomical tables of Eustachio Manfredi (1674-1739) and Philippe Desplaces (1659-1736). He wanted to install a gnomon in his new mission of Darmavaram, but the church proved too small. ${ }^{26}$ Boudier was equipped with a telescope and quadrants of nineteen and twenty-six inches, which did not satisfy him. ${ }^{27}$ In $175^{2}$, Boudier complained that he had only an old timepiece made by Thuret, a telescope of twenty-two feet, some smaller, and a reflecting telescope. The Jesuits in India could not afford such costly instruments as the ones sent to China. ${ }^{28}$ Hyacinthe Montjustin (1708-91) travelled with an astrolabe and a compass in hand with the army of Marquis de Bussy-Castelnau (1718-85). ${ }^{29}$

Missionaries also complained about the lack of time and qualified people for carrying out cartographic and astronomical activities. To help gather

23 Louis Patouillet, "Préface," in Lettres édifiantes et curieuses 34 (Paris: Charles-Pierre Berton, ${ }^{1776)}$ ), iv-v. "[...] as said often, a missionary, though zealous, is not always attending to his evangelization ministry: he does not preach, he does not catechize continuously, and, without subtracting anything at the time given to extend the limits of the Church, he has moments, somewhat at his disposal that he can use for the progress of science. He then informs his homeland, happy to dedicate the labours that the apostolic functions permit him." A similar point is developed by Antonella Romano for Eusebio Kino's work in Mexico. See Antonella Romano, "Les jésuites entre apostolat missionnaire et activité scientifique, in Archivum historicum Societatis Jesu 74 (2005): 227-28. She notes, however, that only few missionaries were concerned with scientific activities.

24 See the notes by Abbé Brottier on observations of latitudes: Changernagor by Boudier $\left(22^{\circ} 51^{\prime}\right)$ and Pondicherry in $1726\left(11^{\circ} 57^{\prime}\right)$; Vencataguiri $\left(12^{\circ} 53^{\prime} 55^{\prime \prime}\right)$ in 1730 and Boucapouram $\left(15^{\circ} 37^{\prime}\right)$ by Gargam; Ballapouram $\left(13^{\circ} 23^{\prime} 19^{\prime \prime}\right)$ in 1729 by Gargam and Calmette, AsJP, G Bro 83 f.161.

25 Ducros to Souciet, 1725, ASJP, G Bro 88 f.109.

26 Gargam to his brother and to Souciet, $173^{0}-32$, AsJP. G Bro 82 ff. $86-96$.

27 Boudier to Souciet, Chandernagor, January 18, 1736, AsJP. G Bro 88 f.143.

28 Boudier to Delisle, Chandernagor, January 13, 1753, Bibliothèque de l'Observatoire, Paris, $\mathrm{B} 1 / 7 / 198$.

29 Cœurdoux to Delisle, Pondicherry, October 14, 1755, AN. Mar $2 \mathrm{JJ} 66 \mathrm{n}^{\circ} 38$. 
information Jesuits depended on local informers or go-betweens. ${ }^{30}$ Indians were very good at pointing a direction but less so with distances. ${ }^{31}$ In part, this was because the travelers' interpreters translated under the terms "coss" or "leagues" all the itinerary measures used in India, which varied from one place to the other. ${ }^{32}$ Mentions of distances were thus distorted, and d'Anville faced the challenge of aligning all these indications. ${ }^{33}$ Jesuits, especially GastonLaurent Cœurdoux (1691-1779) who himself knew Telugu and Sanskrit, referred to their catechists from India or any person in their circle generally as "informers." Unlike the Jesuit informers involved in Oriental studies, however, those involved in cartography might not be literate or elite. ${ }^{34}$ Since ancient times, Indian travelers and merchants had used itineraries or tables of places, but it is difficult to determine the exact articulation of this knowledge with Jesuit cartography given the paucity of sources that survive. ${ }^{35}$ Nor do we know the extent to which they used the skills of Indians to draw and label the cartographic artefacts offered as diplomatic gifts, such as the map with Telugu names given by Antonio Rubino (1578-1643) to the king of Vijayanagar in 1606, or the globe with Tamil captions presented by Bouchet to the king of Madurai in $1700 .^{36}$

30 Moriset to Souciet, Pondicherry, January 26, 1731, ASJP. G Bro 83 f. 117. In this letter, Moriset complains that the best Jesuit mathematicians go to China instead of India. On gobetweens, see Kapil Raj et al., Relocating Modern Science.

31 Cœurdoux to Delisle, Pondicherry, October 14, 1755, AN. Mar 2 JJ $66 \mathrm{n}^{\circ} 38$.

32 Gustave-Laurent Cœurdoux [attrib.], "Divers mémoires pour servir à la perfection de la carte des Indes orientales recueillis par un missionnaire," in Description historique et géographique de l'Inde ed. Jean II B Bernouilli, 3, no. 2 (Berlin: Pierre Bourdeaux, 1789), 110.

33 Jean-Baptiste d'Anville, Eclaircissemens géographiques sur la carte de l'Inde (Paris: Imprimerie royale, 1753), 7-14. Courdoux elaborated in Courdoux to Delisle, Pondicherry, 1760, in Lettres édifiantes et curieuses concernant l'Asie, l'Afrique et l'Amérique, ed. M. L. Aimé-Martin (Paris: Mairet et Fournier, 1849), 762.

34 Dhruv Raina, "The French Jesuit Manuscripts on Indian Astronomy," in Looking at It from Asia, ed. Florence Bretelle-Establet (Dordrecht: Springer, 2010), 115-40; Ines Županov, Disputed Mission (Oxford: Oxford University Press, 1999) and Missionary Tropics: The Catholic Frontier in India (Ann Arbor: University of Michigan Press, 2005); and Sylvia Murr, L'Inde philosophique entre Bossuet et Voltaire: Moeurs et coutumes des Indes (1777) (Paris: École française d'Extrême-Orient, 1987).

35 Joseph E. Schwartzberg, "Introduction to South Asian Cartography," in History of Cartography 2:1, ed. John Brian Harley and David Woodward (Chicago: Chicago University Press, 1992), 317-23.

36 Joan-Pau Rubiés, “The Jesuit Discovery of Hinduism: Antonio Rubino's Account of the History and Religion of Vijayanagara (1608)," Archiv für religionsgeschichte 3, no. 1 (2001): 210-56, here 219. Sumathi Ramaswamy, Terrestrial Lessons: The Conquest of the World as Globe (Chicago: Chicago University Press, 2017), 22-23. Danna Agmon, "Conflicts in the 
Guillaume Delisle used numerous Jesuit maps and itineraries sent to France for his map of South India published in 1723 as did Jean-Baptiste d'Anville for his map of India of $175^{2 .}{ }^{37}$ Delisle copied the Eastern Ghats and their forests from the 1722 Jesuit map. He added many place names and extended the map, using Jean-Baptiste Tavernier's and Pierre Mauduit's itineraries. ${ }^{38}$ Adding to this data for the 1737 map, d'Anville continued to collect and analyze material from the Jesuits. He benefitted, for example, from information given by Xavier Duchamp (1693-1740) on Vijayanagar as well as the itinerary from Chandernagor to Jaipur by Boudier and Jean François Pons (1688-1752). This latter map, though adopting the new framing of the full peninsula, largely reflects the spatial activity of the French, especially the French East India Company, centered in South India. ${ }^{39}$

After Souciet's death in 1744 the Jesuits' scientific work seem to have shifted to an external dynamic, as Antonella Romano has argued. ${ }^{40}$ In $175^{1}$ and $175^{2}$, Courdoux and Boudier entered into a triangular correspondence with JosephNicolas Delisle (1688-1768) at his request, which was subsequently expanded to include Antoine Gaubil (1689-1759) in China. ${ }^{41}$ As astronomer of the Dépôt des cartes et plans de la Marine, Delisle sent to the missionaries the latest maps, asking for corrections, insisting on the use of observations to determine the exact position of a place. As a member of the Académie des Sciences, Delisle placed himself as an intermediary between Europe and observers in Asia, and promoted the use of the Jesuit network to collect data for the advance

Context of Conversion: French Jesuits and Tamil Religious Intermediaries in Madurai," in Intercultural Encounter and Jesuit Mission in India (16th-18th Centuries), ed. Anand Amaladass and Ines Županov (Bangalore: Asian Trading Corporation, 2014), 179-98.

37 Guillaume Delisle, "Carte des Côtes de Malabar et de Coromandel, presentee au Roy" (Paris: G. Delisle, 1723), BnF, G в в в 565 (14, 36), http://gallica.bnf.fr/ark:/12148/btvib59730594/ f1.item, accessed December 7, 2017; Jean-Baptiste d'Anville, "Carte de l'Inde dressée pour la Compagnie des Indes” (Paris: d'Anville, November 1752), BnF, GE DD-2987 (6817 B), http://gallica.bnf.fr/ark:/12148/btvıb53052830q/fi.item, accessed December 7, 2017.

38 Pierre Mauduit (1664-1711), who arrived in India in 1699, helped found the mission of Carnate and later the superior (1704-11). His 1701 itinerary in Carnate appeared in Lettres édifiantes, 508 and in German with a map in Joseph Stöcklein, Allerhand so Lehr-als Geistreiche Brief (Augsburg: Philipp Martin, 1726), 76:64-69.

39 Matthew H. Edney, Mapping an Empire: The Geographical Construction of British India 1765-1843 (Chicago: University of Chicago Press, 1997), 5-8.

40 Antonella Romano, "Les jésuites entre apostolat missionnaire et activité scientifique," Archivum historicum Societatis Jesu 74 (2005): 213-36, here 230.

41 Delisle to Cœurdoux, Paris, January 18, 1752, Bibliothèque de l'Observatoire, Paris [hereafter OBSPM], B1/6/197. 
of science. Consciously or not, the French Jesuits in India became part of a "colonial machine" as defined by James McClellan and François Regourd. But this machine had complex and global political, administrative and commercial goals as well as cultural and scientific aims, and it did not merely serve to extend French territorial power. ${ }^{42}$

The main informer of Delisle in the field of geography, Cœurdoux entered the Society of Jesus in 1715 and arrived in India in 1732. After difficult years in the mission of Carnate, he was appointed chief of the new mission in Kareical in 1739 . From 1744 to 1751 , he served as the superior of the Jesuits in Pondicherry. He distinguished himself by his apostolate as well as his intellectual works. His numerous letters published in the Lettres édifiantes et curieuses deal with subjects related to natural history, Sanskrit and Indian languages, hinduism, textile industry and geography. ${ }^{43}$ In 1753 , he observed the passage of Mercury with Jean-Baptiste du Choisel (1717-93), professor of hydrography in Pondicherry.

Cœurdoux sent Delisle maps drawn after the voyages of Montjustin and corrections for the main French maps of his times, giving special attention to toponyms and correcting names after the local languages, a characteristic of Jesuit maps. ${ }^{44}$ The map of the voyages of Montjustin from Masulipatnam to Hyderabad with scales of latitude and longitude shows the army's marches with indications on the surrounding landscape of rivers, fortresses, trees, and mountains. ${ }^{45}$ Cœurdoux had compiled and checked the information before having the map drawn by a "Sieur Fortin," probably a pilot who was familiar with nautical charts. ${ }^{46}$

The other correspondent of Delisle, Boudier entered the Society of Jesus in 1701 and left for India in 1718. Stationed in Bengal, he made many observations, mainly of eclipses of the moon and satellites of Jupiter, which permitted him to fix the position of Chandernagor. His fellow missionaries considered him to

42 McClellan and Regourd, The Colonial Machine, 184-86.

43 Léon Besse, "Liste alphabétique des missionnaires du Carnatic de la Compagnie de Jésus au XVIII ${ }^{\mathrm{e}}$ siècle," Revue historique de l'Inde française 2 (1918): 27-33.

Remarks of Cœurdoux on Guillaume Delisle's map of South India, 1739. AN. Mar 3 JJ 361 pièce 7. Another memoir is in the Delisle papers in AN. Mar $2 \mathrm{JJ} 69$ pièce 12b. For D'Après see Gustave-Laurent Cœurdoux, "Diverses remarques sur les cartes des Indes orientales, sur la carte et le routier de M. D’Après" (after 1751), AN. Mar $3 \mathrm{JJ} 338$ pièce 18.

$45 \quad$ AN, Mar $2 \mathrm{JJ} 69$ pièce 12.

46 Cœurdoux to Delisle, Pondicherry, October 14, 1755, AN. Mar $2 \mathrm{JJ} 66 \mathrm{n}^{\circ} 38$. These maps and memoirs, sent by Joseph Jérôme Lefrançois de Lalande (1732-1807), were eventually published by Jean II Bernoulli rather than Delisle in the third volume of the Description historique et géographique de l'Inde 3, no. 2 (Berlin: Pierre Bourdeaux, 1786), 109-203. 
be the specialist in astronomy. ${ }^{47}$ Thanks to his reputation, the Maharaja Savai Jai Singh (1688-1743) invited him to work in his observatories in Jaipur and Delhi. After returning to Chandernagor, Boudier sent Souciet and Du Halde a small map depicting his route with a memoir. ${ }^{48}$ In 1751 , Boudier sent a corrected map to Pierre Foureau (1700-49), a former missionary in China, which Joseph-Nicolas Delisle subsequently obtained..$^{49}$ It contained valuable data on a region little known to Europeans, gleaned from Jean Law de Lauriston's (171799) marches along the Ganga (Ganges), from Jean-Baptiste Gentil's (1726-99) maps of Oudh, and, more than anything from the work of Joseph Tieffenthaler (1710-83), an Austrian Jesuit. Of those who developed Boudier's work, Tieffenthaler was perhaps the most important to the future mapping of India by the British. From 1766 to 1771, Tieffenthaler explored the Oudh region and the Ganga River along with its tributary the Ghaghara River from the city of Patna. He drew a map of the Ganga and Ghaghara with the help of local observers and indigenous maps. Jean III Bernouilli (1744-1807) eventually published this manuscript along with many other memoirs between 1784 and 1789 , work that was also used by the English geographer James Rennell (1742-1830), thought of in the nineteenth century as the "Father of Indian Geography." 50

Jesuits have been credited with being the first Indologists and having introduced elements of Hindu astronomy in Europe. ${ }^{51}$ In the same way, as sensed by Bouchet in the letter quoted at the beginning of this article, the Jesuit mission became instrumental in the mapping of the interior of India. Because of the leading position of Parisian cartographers in the eighteenth century, French Jesuits became the main contributors of mapping India in Europe, able observers due to their deep scientific and mathematical education even if their best mathematicians went to China. Their maps of India produced during the first

47 Gargam to Souciet, Darmavaram, July 19, 1732, ASJP, G BRo 82 f.96; Cœurdoux to Delisle, Pondicherry, February 12, 1753, AN, Mar 2 JJ 69 pièce 12a.

48 Delisle to Boudier, Paris, November 1, 1751, овSPм, B1/6/175. Delisle had found the map in Souciet's paper, but the memoir was lost. He asked therefore to send him a copy of the memoir.

49 Delisle to Boudier, Paris, October 13, 1752, овSPM, B1/6/253. This map has not been traced in French archives yet.

5o Michaël Severninck, "Geographical Mapping of India in the $18^{\text {th }}$ Century: The Contribution of the German Jesuit Joseph Tief[f]enthaler (1710-85)," in Intercultural Encounter and Jesuit Mission in India (16th-18th centuries), ed. Anand Amaladass and Ines G. Županov (Bangalore: Asian Trading Corporation, 2014), 290-320.

51 Jean Filliozat, "La naissance et l'essor de l'indianisme," Bulletin de la Société des études indochinoises 29 (1934): 269-76; and Raina, "The French Jesuit Manuscripts on Indian Astronomy." 
half of the eighteenth century represent the conjunction of the wish of French monarchy through the Académie des Sciences to have accurate geographical information as tools for colonial domination, and the broader Jesuit tradition of trying to map the regions to Christianize, to develop Catholic knowledge and to use this science in Europe to profit of the missions. Yet, in the end, the result was not a French empire in India like the Spanish in the Americas or the Qing in China but a complex prelude to the British, one in which Parisian royal scientific institutions, commercial printers in Paris, the Jesuit mission in India, and Indian go-betweens unwittingly all played important roles in defining. 